Agro-Science Journal of Tropical Agriculture, Food, Environment and Extension Volume 11 Number 2 May 2012 pp $17-23$

\title{
ISSNIII9-7455
}

\section{INTERRELATIONSHIP AND PATH COEFFICIENT ANALYSIS OF MORPHO- PHYSIOLOGICAL TRAITS AMONG MAIZE (ZEA MAYS L.) DIALLELIC CROSSES IN THE SOUTHERN GUINEA SAVANNA OF NIGERIA}

\author{
Bello, O. B. ${ }^{*}{ }^{1}$, Ige, S. A. ${ }^{2}$, Abdulmaliq, S. Y. ${ }^{3}$ and Afolabi, M. S. ${ }^{4}$ \\ ${ }^{1}$ Department of Biological Sciences, Fountain University, Osogbo, Osun state, Nigeria. \\ ${ }^{2}$ Department of Agronomy, University of Ilorin, Ilorin, Nigeria. \\ ${ }^{3}$ Department of Agronomy, Ibrahim Badamasi Babangida University, Lapai, Niger State, Nigeria. \\ ${ }^{4}$ Department of Crop Science, Landmark University, Omuaran, Kwara State, Nigeria. \\ *corresponding author. e-mail: obbello2002@yahoo.com.
}

\begin{abstract}
This study was done to determine the effect of the grain yield and its related characteristics on 10 openpollinated maize varieties and their $45 F_{1}$ hybrids using correlation and path coefficient analysis. A two-year study was conducted on maize genotypes at the University of Ilorin Teaching and Research Farm Ilorin, Nigeria, during 2005 and 2006 growing seasons. Positive and significant phenotypic and genotypic correlations were found for days to 50\% tasselling with plant and ear heigh $t$, and grain yield with plant height, number of grains ear $^{-1}$ and ear weight. Positive and significant environmental correlation was also recorded for grain yield with plant and ear height, and ear weight. The path analysis revealed that, days to 50\% silking, ear weight and number of grains ear ${ }^{-1}$ had the highest direct effect on grain yield, while number of grains ear ${ }^{-1}$ had the highest moderate indirect negative effects on grain yield. Days to flowering, plant and ear height, number of grains ear ${ }^{-1}$ and ear weight could be the important selection criteria in improving open pollinated maize varieties and hybrids for high grain yield.
\end{abstract}

Key words: Phenotypic, genotypic correlation, open pollinated varieties, yield characters

\section{INTRODUCTION}

Maize (Zea mays L.) is an important staple food crop and provides bulk of raw materials for the livestock and many agro-allied industries in the world. Plant breeders are interested in developing cultivars with improved yield and other desirable agronomic and phenological characters. In order to achieve this goal, the breeders had the option of selecting desirable genotypes in early generations or delaying intense selection until advanced generations (Puri et al., 1982). The selection criteria may be yield, or one or more of the yield component characters. However, breeding for high yield crops require information on the nature and magnitude of variation in the available materials, relationship of yield with other agronomic characters and the degree of environmental influence on the expression of these component characters. Grain yield in maize is quantitative in nature and polygenically controlled therefore effective yield improvement and simultaneous improvement in yield characters are very important (Bello and Olaoye, 2009). Selection on the basis of grain yield character alone is usually not very effective and efficient. However, selection based on its component characters could be more efficient and reliable (Muhammad et al., 2003). Knowledge of association between yield and its component traits and among the component parameters themselves can improve the efficiency of selection in plant breeding. Correlation coefficient measures the mutual association between a pair of variables independent of other variables to be considered. Where more than two variables are involved, correlation coefficient alone does not give complete picture of the interrelationship (Fakorede and Opeke 1985). To determine relationships, correlation analyses are used such that the values of two characters are analyzed on a paired basis, results of which may be either positive or negative. The result of correlation is of great value in the evaluation of the most effective procedures for selection of superior genotypes. When there is positive association of major yield characters, component breeding would be very effective but when these characters are negatively associated, it would be difficult to exercise simultaneous selection for them in developing a variety (Nemati et al., 2009).

Path coefficient analysis is a standardized partial regression coefficient that allows partitioning of 
correlation coefficient into direct and indirect effects of various traits towards dependent variable, and also helps in assessing the cause-effect relationship as well as effective selection. Path analysis plays an important role in determining the degree of relationship between yield and its components. Studies of correlation and path analysis have recently been conducted in groundnut by Izge et al., (2004); in sorghum by Ezeaku and Mohammed, (2006); in pear millet by Izge et al., (2006) and in pea by Togay et al., (2008). Researchers have also attempted been to determine the association between the characters for selection of high maize grain yield. Findings from two independent studies, (You et al., 1998; Annapurna et al., 1998) revealed positive and significant correlations between grain yield and number of rows ear ${ }^{-1}$, number of grains row $^{-1}$. Khatun et al. (1999) and Batool et al. (2012) reported that grain yield plant ${ }^{-1}$ was positively and significantly correlated with number of grains ear ${ }^{-1}$, ear weight, 1000-grain weight and ear height. Orlyan et al. (1999) and Gautam et al. (1999) suggested that most important characters in improving maize grain yield are number of grains row ${ }^{-1}$, number of grain ear $^{-1}$ and plant height. However, Mohammad et al. (2003) determined the interrelationship between grain yield and its components from eighteen maize lines/hybrids, using genotypic correlation and path coefficient analysis. Grain yield was positively and significantly associated with plant and ear height, ear diameter, number of grains ear ${ }^{-1}$, number of grains row $^{-1}$ and 1000-grain weight. Geetha and Jayaraman (2000) studied direct and indirect effects of different quantitative traits on grain yield in 90 hybrids and reported that number of grains ear $^{-1}$ exerted a maximum direct effect on grain yield. They therefore suggested that selection of number of grains ear ${ }^{-1}$ could be highly effective for improvement of grain yield. Kumar and Kumar (2000) also stressed that plant height with higher number of grains row $^{-1}$, ear weight, and number of grains $e^{-1}$ could be selected for high yielding.

Review of literatures shows that determining relationships between yield and its components is essential for high maize yield. Although all the experimental results were not in agreement with one another, but in most experiments, some yield parameters such as number of grains $e^{-1}$ and ear weight feature prominently in improving grain yield. Thus, by determining association between maize grain yield and yield components and between yield components themselves as well as recognition of the parameters that have significant effect on yield, is a prerequisite plan for a meaningful breeding programme. The objectives of the present research therefore was to determine the association between maize grain yield and some other agronomic characters with the view to identifying characters whose selection could be used in improving grain yield.

\section{MATERIALS AND METHODS}

Ten open pollinated maize varieties (OPVs) developed for grain yield and adaptation to abiotic (drought) and biotic (Stalk rot, Striga and Downy mildew) stresses were obtained from the International Institute of Tropical Agriculture (IITA), Ibadan, Nigeria. They are early to medium maturing white cultivars with maturity period of 90 to 100 days. The origin, genetic background, breeding emphasis and ecological adaptation of the maize parents are shown in Table 1 . The ten varieties were crossed in a partial diallel to generate $45 \mathrm{~F}_{1}$ hybrids during 2004 and 2005 growing seasons at the Teaching and Research ( $\mathrm{T}$ and R) farm of University of Ilorin (Latitude $8029^{\prime} \mathrm{N}$, Longitude $4035^{\prime} \mathrm{E}$ and annual average rainfall of 945 $\mathrm{mm})$. The resultant hybrids were harvested, processed and stored in the cold room prior to field evaluation. It is worthwhile to note that the ultimate goal is not diallel analysis in which using pure lines as parents is necessary. Soil samples were collected from the trial site before cropping and were analyzed in the laboratory for selected physical and chemical properties and presented in Table 2. The soil texture is loamy sand. At $0-15 \mathrm{~cm}$ depth, the amounts of silt, sand and clay were 8,84 and 8 respectively, with soil $\mathrm{pH}=$ 7.30 and $\mathrm{CEC}=2.83\left(\mathrm{Cmol} \mathrm{kg}^{-1}\right)$.

The parents and hybrids were evaluated using a randomized complete block design (RCBD) with 4 replicates in 2005 and 2006. Entries were made in 4row plots of $5 \times 1.5 \mathrm{~m}$ each and planted at inter-row spacing of $75 \mathrm{~cm}$ and within row spacing of $50 \mathrm{~cm}$ to achives a population of about 53,333 plants ha ${ }^{-1}$. Three seeds were initially planted per hill and were thinned to two plants per hill. Fertilizer was applied in splitdosage at three and seven weeks after planting (WAP) at the rate of $80 \mathrm{~kg} \mathrm{~N}, 60 \mathrm{~kg} \mathrm{P}$ and $60 \mathrm{~kg} / \mathrm{ha} \mathrm{K}$ respectively from compound NPK fertilizer (20-10-10). Agronomic parameters measured in each year were seedling emergence, days to $50 \%$ tasselling, pollen shed and silking; anthesis-silking interval, plant and ear height $(\mathrm{cm})$, number of grains ear ${ }^{-1}$ and ear weight. Plant height was measured from soil level to the node of the flag leaf and to the highest ear-bearing node respectively at harvest stage. Days to 50\% tasselling, pollen shed and silking were calculated as the number of days from planting to when $50 \%$ of the population have tasseled, shed pollen and silked respectively. Anthesis-silking interval was estimated as the difference between days to pollen and silking, and grain yield (t/ha) measured after adjusting to $12 \%$ moisture content. Combined analysis of variance and means over years were computed using SAS PROC, (1999) for the parents OPVs and hybrids with respect to grain yield and other agronomic parameters respectively. The phenotypic (rph), genotypic (rg) and environmental (re) correlation coefficients were estimated from the mean squares and mean across products as suggested by Mode and Robinson (1959). 
The correlation coefficients were partitioned into direct and indirect effects using the path coefficient analysis according to Dewey and Lu (1959).

\section{RESULTS AND DISCUSSION}

In the study, phenotypic and genotypic correlation coefficients calculated among examined characteristics in maize genotypes are presented in Table 3 and 4. The correlation coefficients of the pairs of characters revealed the presence of significant and positive $(\mathrm{p}<0.05)$ phenotypic correlation of grain yield $\mathrm{ha}^{-1}$ with days to $50 \%$ tasselling $(\mathrm{rph}=0.34 *)$, plant height $\left(\mathrm{rph}=0.56^{*}\right)$ and ear height $\left(\mathrm{rph}=0.45^{*}\right)$, number of grains ear $^{-1}\left(\mathrm{rph}=0.59^{*}\right)$, and ear weight $(\mathrm{rph}=$ $0.46^{*}$ ) (Table 3). This indicated that by increasing these attributes, could invariably increase grain yield. Khatun et al. (1999) and Babaji et al. (2010) found that grain yield plant $^{-1}$ was positive and significantly correlated with number of kernels ear ${ }^{-1}$, ear weight and ear insertion height. High correlation of grain yield with plant height is also reported by other researchers (Annapurna et al., 1998; Gautam et al., 1999; Batool et al. 2012; Sali et al. 2012). The relationship between seedling emergence and number of grains ear ${ }^{-1}$ was also positive and significant, indicating that early emergence genotypes could result in increased number of grains ear ${ }^{-1}$ and consequently increase grain yield. Days to anthesis was positive and significantly $(\mathrm{P}<$
$0.05)$ associated with plant and ear height and number of grains ear ${ }^{-1}$. Troyer and Larkins (1985) observed that plant height was positively correlated with days to flowering morphologically, as internodes' formation stops at floral initiation, and that early flowering maize varieties are usually shorter in height. Genotypic correlation coefficients (Table 4) followed a similar trend in magnitude and significance with that of phenotypic coefficients, except plant and ear height with negative and non-significant correlation with number of grains ear ${ }^{-1}$. There were positive significant phenotypic and genotypic correlations of days to flowering with plant and ear height; and grain yield with plant height, number of grain ear $^{-1}$ and ear weight. This suggests that genetic factors are responsible for these associations. Therefore, plant height, number of grain ear ${ }^{-1}$ and ear weight could also be considered for selection and improvement for high yielding varieties. Even though, both phenotypic and genotypic correlations were comparable in magnitude, the genotypic correlations were of higher magnitude than their corresponding phenotypic correlations, indicating a strong inherent relationship among the characters studied.

\section{Table 1. Origin, characteristic features and ecological adaptation of 10 open pollinated maize varieties}

\begin{tabular}{llll}
\hline & Genotypes & Origin and characteristic features & $\begin{array}{l}\text { Ecological } \\
\text { adaptation }\end{array}$ \\
\hline 1. & Acr 90 Pool 16-Dt & $\begin{array}{l}\text { Early white dent International Maize and Wheat Improvement Centre CIMMYT } \\
\text { cultivar with stalk rot, striga and drought tolerance. }\end{array}$ & Forest and savannah. \\
2. & Tze Comp 4-Dmr Srbc2 & $\begin{array}{l}\text { Early maturing white and semi dent cultivar with higher yield and striga tolerance. } \\
\text { Early maturing white and semi dent cultivar with higher yield and striga tolerance. }\end{array}$ & Forest and savannah. \\
3. & Tze Comp4 C2 & Early and savannah. \\
4. & Acr 97 Tze Comp3 C4 & Earle flint dent cultivar with higher yield, downy mildew and striga tolerance & Forest and savannah. \\
5. & Hei 97 Tze Comp3 C4 & Early white flint dent cultivar with higher yield, downy mildew and striga tolerance. & Forest and savannah. \\
6. & Acr 94 Tze Comp5 & Early white flint dent cultivar with striga tolerance. & Savannah. \\
7. & Tze Comp3 Dt & Early white flint dent cultivar with drought tolerance. & Forest and savannah \\
8. & Tze Comp3 C2 & Early white and flint dent cultivar with downy mildew and striga tolerance. & Forest and savannah. \\
9. & Ak 95 Dmr-Esrw & Early maturing and flint dent cultivar with downy mildew and striga tolerance. & Forest. \\
10. & Tze Msr-W & Early white semi dent cultivar with higher yield and striga tolerance & Forest and savannah. \\
\hline
\end{tabular}

Source: IITA Archival Report 1988-1992 
Table 2. Selected physical and chemical characteristics of the soil before cropping of maize

\begin{tabular}{|c|c|c|}
\hline Soil properties & Value of $0-15 \mathrm{~cm}$ depth & Value of $15-30 \mathrm{~cm}$ depth \\
\hline Texture & Loamy sand & Loamy sand \\
\hline Soil PH (water) & 7.30 & 6.30 \\
\hline Sand $\%$ & 84.00 & 88.00 \\
\hline Clay \% & 8.00 & 8.00 \\
\hline Silt $\%$ & 8.00 & 4.00 \\
\hline Exchangeable $\mathrm{Ca}^{2+}\left(\mathrm{Cmol} \mathrm{kg}^{-1}\right)$ & 1.10 & 2.10 \\
\hline Exchangeable $\mathrm{Mg}^{2+}\left(\mathrm{Cmol} \mathrm{kg}^{-1}\right)$ & 1.60 & 2.10 \\
\hline Exchangeable $\mathrm{Na}^{+}\left(\mathrm{Cmol} \mathrm{kg}^{-1}\right)$ & 0.18 & 0.19 \\
\hline Exchangeable $\mathrm{K}^{+}\left(\mathrm{Cmol} \mathrm{kg}^{-1}\right)$ & 0.01 & 0.01 \\
\hline Total acidity $\mathrm{H}^{+}\left(\mathrm{Cmol} \mathrm{kg}^{-1}\right)$ & 0.04 & 0.04 \\
\hline Cation exchange capacity $\left(\mathrm{Cmol} \mathrm{kg}^{-1}\right)$ & 2.83 & 4.44 \\
\hline$\%$ Organic Carbon & 0.26 & 0.33 \\
\hline$\%$ Total Nitrogen & 1.30 & 0.90 \\
\hline Available $\mathrm{P}\left(\mathrm{Mg} \mathrm{kg}^{-1}\right)$ & 4.10 & 3.80 \\
\hline
\end{tabular}

Table 3. Analysis of phenotypic correlation for maize grain yield and other agronomic characters combined across years in Ilorin, Nigeria

\begin{tabular}{|c|c|c|c|c|c|c|c|c|c|c|}
\hline & $\begin{array}{l}\text { Seedling } \\
\text { emergence }\end{array}$ & $\begin{array}{l}\text { Days to } 50 \% \\
\text { tasselling }\end{array}$ & $\begin{array}{l}\text { Days to } 50 \% \\
\text { pollen shed }\end{array}$ & $\begin{array}{l}\text { Days to } \\
50 \% \\
\text { silking }\end{array}$ & $\begin{array}{l}\text { Anthesis- } \\
\text { silking } \\
\text { interval }\end{array}$ & 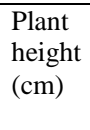 & $\begin{array}{l}\text { Ear height } \\
(\mathrm{cm})\end{array}$ & $\begin{array}{l}\text { Number } \\
\text { of grain } \\
\text { ear }\end{array}$ & $\begin{array}{l}\text { Ear } \\
\text { weight } \\
\text { (t/ha) }\end{array}$ & $\begin{array}{l}\text { Maize } \\
\text { grain } \\
\text { yield } \\
\text { (t/ha }\end{array}$ \\
\hline Seedling emergence & 1.00 & & & & & & & & & \\
\hline Days to $50 \%$ tasselling & 0.02 & 1.00 & & & & & & & & \\
\hline $\begin{array}{l}\text { Days to } 50 \% \text { pollen } \\
\text { shed }\end{array}$ & 0.01 & 0.07 & 1.00 & & & & & & & \\
\hline Days to $50 \%$ silking & 0.03 & 0.06 & 0.05 & 1.00 & & & & & & \\
\hline Anthesis-silking interval & 0.05 & 0.02 & 0.02 & 0.05 & 1.00 & & & & & \\
\hline Plant height $(\mathrm{cm})$ & 0.04 & $0.57 *$ & 0.04 & 0.04 & 0.04 & 1.00 & & & & \\
\hline Ear height $(\mathrm{cm})$ & 0.02 & $0.72 *$ & 0.12 & 0.07 & 0.08 & 0.11 & 1.00 & & & \\
\hline Number of grain ear ${ }^{-1}$ & 0.07 & $0.45^{*}$ & 0.45 & 0.08 & 0.05 & $0.47 *$ & $0.53^{*}$ & 1.00 & & \\
\hline Ear weight (t/ha) & 0.05 & 0.05 & 0.08 & $0.67 *$ & 0.05 & $0.71^{*}$ & 0.02 & 0.03 & 1.00 & \\
\hline Maize grain yield (t/ha) & 0.04 & $0.34 *$ & 0.04 & 0.05 & 0.06 & $0.56^{*}$ & $0.45^{*}$ & $0.59 *$ & $0.46^{*}$ & 1.00 \\
\hline
\end{tabular}

$*$, Significant at $<0.05$ level of probability.

Table 4. Analysis of genotypic correlation for maize grain yield and other agronomic characters combined across years in Ilorin, Nigeria

\begin{tabular}{|c|c|c|c|c|c|c|c|c|c|c|}
\hline & $\begin{array}{l}\text { Seedling } \\
\text { emergence }\end{array}$ & $\begin{array}{l}\text { Days to } \\
50 \% \\
\text { tasselling }\end{array}$ & $\begin{array}{l}\text { Days to } 50 \% \\
\text { pollen shed }\end{array}$ & $\begin{array}{l}\text { Days to } \\
50 \% \\
\text { silking }\end{array}$ & $\begin{array}{l}\text { Anthesis- } \\
\text { silking } \\
\text { interval }\end{array}$ & $\begin{array}{l}\text { Plant } \\
\text { height } \\
(\mathrm{cm})\end{array}$ & $\begin{array}{l}\text { Ear } \\
\text { height } \\
(\mathrm{cm})\end{array}$ & $\begin{array}{l}\text { Number } \\
\text { of grain } \\
\text { ear }^{-1}\end{array}$ & $\begin{array}{l}\text { Ear } \\
\text { weight } \\
\text { (t/ha) }\end{array}$ & $\begin{array}{l}\text { Maize } \\
\text { grain } \\
\text { yield } \\
\text { (t/ha }\end{array}$ \\
\hline Seedling emergence & 1.00 & & & & & & & & & \\
\hline Days to $50 \%$ tasselling & 0.02 & 1.00 & & & & & & & & \\
\hline Days to $50 \%$ pollen shed & 0.12 & 0.02 & 1.00 & & & & & & & \\
\hline Days to $50 \%$ silking & 0.02 & 0.05 & $0.45^{*}$ & 1.00 & & & & & & \\
\hline Anthesis-silking interval & 0.01 & 0.07 & 0.02 & 0.03 & 1.00 & & & & & \\
\hline Plant height $(\mathrm{cm})$ & 0.05 & $0.74 *$ & 0.05 & $0.45^{*}$ & $0.42 *$ & 1.00 & & & & \\
\hline Ear height $(\mathrm{cm})$ & 0.02 & $0.54 *$ & 0.07 & 0.02 & 0.06 & 0.09 & 1.00 & & & \\
\hline Number of grain ear ${ }^{-1}$ & $0.35^{*}$ & 0.02 & 0.02 & 0.05 & 0.02 & -0.07 & -0.02 & 1.00 & & \\
\hline Ear weight (t/ha) & 0.02 & 0.05 & 0.04 & $0.43^{*}$ & $0.35^{*}$ & $0.34 *$ & $0.37 *$ & 0.02 & 1.00 & \\
\hline Maize grain yield (t/ha) & 0.02 & 0.08 & 0.02 & 0.03 & 0.08 & $0.44 *$ & 0.05 & $0.34 *$ & $0.43^{*}$ & 1.00 \\
\hline
\end{tabular}

Significant at $<0.05$ levels of probability 
Table 5. Analysis of environmental correlation for maize grain yield and other agronomic characters combined across years in Ilorin, Nigeria

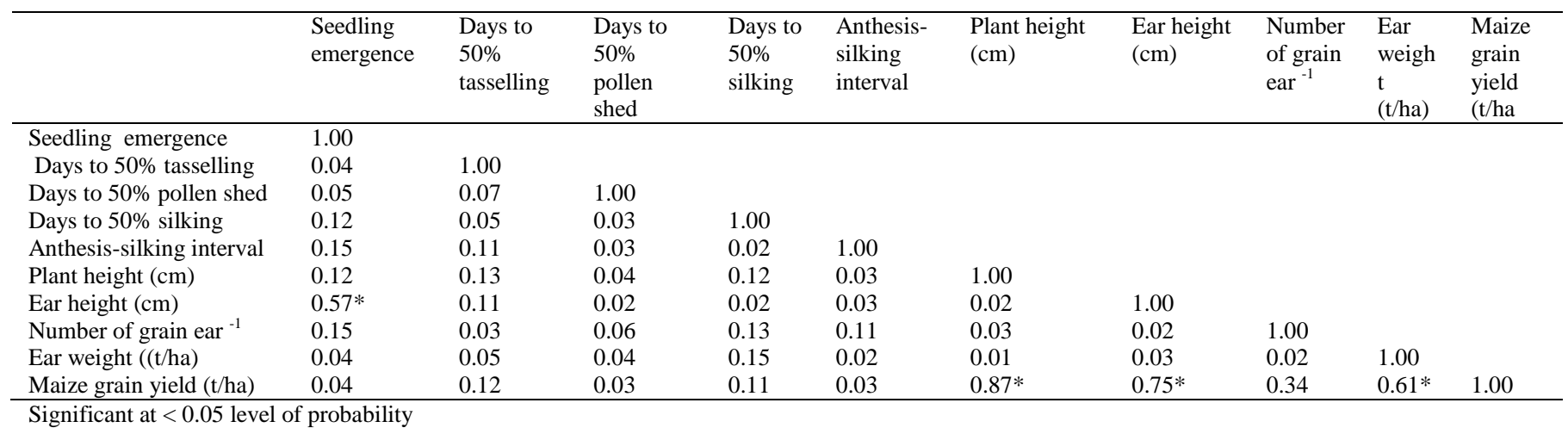

Table 6. Path coefficient analysis of grain yield of maize genotypes combined across years in Ilorin, Nigeria

\begin{tabular}{|c|c|c|c|c|c|c|c|c|c|c|c|c|c|}
\hline \multicolumn{2}{|c|}{ Character } & \multirow{2}{*}{$\begin{array}{l}\text { Mean } \\
\mathrm{s}\end{array}$} & \multirow{2}{*}{$\begin{array}{l}\text { Direct } \\
\text { effects }\end{array}$} & \multicolumn{9}{|c|}{ Total effects } & \multirow{2}{*}{$\begin{array}{l}\text { Total } \\
\text { effect }\end{array}$} \\
\hline & & & & 1 & 2 & 3 & 4 & 5 & 6 & 7 & 8 & 9 & \\
\hline 1 & Seedling emergence & 38 & 0.191 & & 0.035 & -0.042 & 0.023 & -0.034 & 0.045 & 0.011 & 0.034 & 0.056 & -0.257 \\
\hline 2 & Days to $50 \%$ tasselling & 52 & 0.034 & 0.044 & & 0.045 & 0.032 & 0.056 & 0.033 & 0.054 & 0.045 & -0.034 & 0.854 \\
\hline 3 & $\begin{array}{l}\text { Days to } 50 \% \text { pollen } \\
\text { shed }\end{array}$ & 53 & 0.182 & -0.061 & 0.047 & & 0.034 & -0.045 & 0.067 & -0.066 & 0.067 & 0.065 & 0.452 \\
\hline 4 & Days to $50 \%$ silking & 55 & -0.443 & 0.073 & 0.085 & 0.012 & & 0.044 & 0.056 & 0.034 & -0.065 & 0.034 & 0.245 \\
\hline 5 & Anthesis-silking interval & 3 & 0.147 & 0.046 & 0.047 & 0.041 & 0.045 & & 0.072 & 0.005 & 0.127 & 0.033 & $0.342 *$ \\
\hline 6 & Plant height $(\mathrm{cm})$ & 121 & 0.314 & -0.057 & 0.057 & 0.034 & 0.057 & 0.046 & & 0.006 & 0.072 & 0.256 & -0.234 \\
\hline 7 & Ear height $(\mathrm{cm})$ & 35 & 0.176 & 0.001 & 0.067 & -0.053 & -0.076 & 0.089 & 0.018 & & 0.194 & 0.023 & 0.045 \\
\hline 8 & Number of grain ear ${ }^{-1}$ & 54 & 0.525 & 0.003 & 0.043 & 0.063 & 0.053 & -0.078 & -0.083 & -0.007 & & -0.141 & $0.786^{*}$ \\
\hline 9 & Ear weight (t/ha) & 6.4 & 0.582 & -0.013 & 0.082 & 0.045 & 0.052 & 0.098 & 0.045 & 0.005 & 0.426 & & $\begin{array}{l}0.843^{*} \\
*\end{array}$ \\
\hline
\end{tabular}

Significant at $<0.05<0.01$ level of probability, respectively

This corroborates with the findings of Sali et al. (2012) and Saleem et al. (2012). Environmental correlation coefficients between studied traits illustrated in Table 5 showed that plant and ear height, and ear weight have highly positive and significant correlation $\left(\mathrm{re}=0.87 *, 0.75^{*}\right.$ and $\left.0.61 *\right)$ with grain yield. Days to plant emergence was also positive and significantly correlated with ear height. Westermann and Crothers (1977) reported that changes in yield and yield components had been attributed to plant's response to its environment which may or may not permit full genetic expression of each character. Thus, plant and ear height, and ear weight could be considered in improving maize yield in the breeding programmes. Significant positive correlations between yield and other agronomic characters that can improve yield are quite desirable in plant breeding, because it facilitates selection process and gains from selection.

Path coefficient analyses was also used to obtain further information on the interrelationships among traits and their effects on grain yield and are presented in Table 6. Ear weight showed the greatest direct effect on grain yield $(\mathrm{pc}=0.582)$, followed by number of grain ear ${ }^{-1}(\mathrm{pc}=0.525)$ and days to $50 \%$ silking $(\mathrm{pc}=0.443)$. Many researchers (Alvi et al. 2003; Nemati et al. 2009; Sreckov et al. 2010; Batool et al. 2012) found that ear weight has direct effect on grain yield. They opined that by increasing ear weight due to more absorption of photo assimilates, the most portion of assimilates remobilizes to grains, and invariably increase grain weight. Days to $50 \%$ silking showed high negative direct effect on grain yield ( $\mathrm{pc}=$ -0.443 ). The number of grains ear $^{-1}$ had the highest moderate indirect positive effects on grain yield by ear weight $(\mathrm{p}=0.426)$, while ear weight had the highest moderate indirect negative effects on grain yield by days to seedling emergence $(p=-0.013)$. This is in agreement with findings of previous researchers (Bocanski et al. 2009; Khazaei et al. 2010). It is also shown that, plant height had the highest moderate indirect positive effects on grain yield by ear weight ( $p$ $=0.256$ ), while number of grain ear $^{-1}$ had the highest moderate indirect negative effects on grain yield by ear height ( $\mathrm{p}=-0.007)$. This is in line with results of earlier workers (Saidaiah et al. 2008; Bocanski et al. 2009). However, It is obvious that other variables could have effects on grain yield. In this study, days to flowering, plant and ear height, number of grains ear ${ }^{-1}$ and ear weight appeared to be the prominent characters that could be used in selecting for high yield, because of their highly significant genotypic and 
phenotypic correlations with grain yield. Similar results were reported by Saidaiah et al. (2008), Sreckov et al. (2010) and Batool et al. (2012). These characters also had the highest direct and indirect effects through most of the other characters. It is therefore, concluded that these agronomic parameters could be considered as important selection criteria in improving open pollinated maize varieties and hybrids for high grain yield.

\section{REFERENCES}

Alvi, M.B, Rafique, M., Tariq, M.S., Hussain, A., Mahmood, T, Sarwar M. (2003). Character association and path coefficient analysis of grain yield and yield components maize (Zea mays L.). Pak. J. Biol. Sci., 6(2): 136-138.

Annapurna, D., Khan HA and Mohammad S (1998). Genotypic-phenotypic correlations and path coefficient analysis between seed yield and other associated characters in tall genotypes of maize. Crop Res. Hisar. 16: 205-209.

Babaji, B.A., Yahaya, R. A., Mahadi, M.A. Jaliya, M.M., Sharifai, A.I., Kura, H.N., Arunah, O.L., Ibrahim, A. and Muhammad, A.A. (2012). Contributions of some selected growth and yield attributes to grain yield of extra-early maize in semiarid zone, Nigeria. Global J. Biosci. Biotech., 1 (1); 116-120.

Batool Z, Danial K, Alireza PA and Farhad S (2012). Correlation and path coefficient analysis for determining interrelationships among grain yield and related characters in corn hybrids (Zea mays L.). Intl J Agri Crop Sci., 4 (20): 1519-1522.

Bello OB and Olaoye G (2009). Combining ability for maize grain yield and other agronomic characters in a typical southern guinea savanna ecology of Nigeria. African Journal of Biotechnology. Vol. 8 (11), pp. 25182522.

Bocanski J, Sreckov Z, Nastasic A. (2009). Genetic and phenotypic relationship between grain yield and components of grain yield of maize (Zea mays L.). Genetika. 41 (2): 145154. Dewey DR and Lu KH (1959). A correlation and path-coefficient analysis of components of crested wheatgrass seed production. Agron. J., 51:515518.

Ezeaku IE, Mohammed SG (2006). Character association and path analysis in grainorghum. Afr. J. Biotechnol. 5 (14): 1337-1340.

Fakorede MAB and Opeke BO (1985). Weather factors affecting the response of maize to planting dates in tropical rain forest location. Exp. Agric., 21: 31-40.

Gautam AS, Mittal RK and Bhandari JC (1999). Correlations and path coefficient analysis in maize (Zea mays L.). Ann. Agri. Biol. Res. 4:169-71.

Geetha K and Jayaraman N (2000). Path analysis in maize (Zea mays L.). Agric. Sci. Digest. 20:60-61.

Izge AU, Alabi SO, Maina YT (2004). Correlation and path analysis of pod yield and yield components of groundnut (Arachis hypogeae L.). J. Sustain. Agric. Environ. 6 (1): 15-21.

Izge AU, Kadams AM and Gungula DT (2006). Studies on character association and path analysis of certain quantitative characters among parental lines of pearl millet (Pennisetum glaucum ) and their $F_{1}$ hybrids in a diallel cross. African Journal of Agricultural Research Vol. 1 (5), pp. 194-198.

Khatun F, Begum S, Motin A, Yasmin S and Islam MR (1999). Correlation coefficient and path analysis of some maize (Zea mays L.) hybrids. Bangladesh J. Bot., 28:9-15.

Khazaei F, Alikhani MA, Yari L, Khandan A. (2010). Study the correlation, regression and path coefficient analysis in sweet corn (Zea mays var. saccharata) under different levels of plant density and nitrogen rate. ARPN J. Agric. Biol. Sci. 5: 14- 19.

Kumar MVN and Kumar SS (2000). Studies on character association and path coefficients for grain yield and oil content in maize (Zea mays L.). Ann. Agric. Res., 21:73-8.

Mode CJ and Robinson HF (1959). Pleiotropism and the genetic variance and covariance. Biometrics 15: 518-537.

Muhammad BA, Muhammad R, Muhammad ST, Amer H, Tariq M, Muhammad SA (2003). Character association and path coefficient analysis of grain yield and yield components in maize. Pakistan Journal of Biological Science, 6 (2); 136- 138. 
Nemati A, Sedghi M, Sharifi RS, Seiedi MN (2009). Investigation of correlation between traits and path analysis of corn (Zea mays L.) grain yield at the climate of Ardabil region (Northwest Iran). Not. Bot. Hort. Agrobot. Cluj 37 (1), 194-198.

Orlyan NA, Zubko DG, Orlyan NA, Goleva GG (1999). Correlation analysis in breeding extra early maturing maize hybrids. Kukuruzai Sorgo, 6: 9-12.

Puri YP, Qualset CO, Williams WA (1982). Evaluation of yield components as selection criteria in barley breeding. Crop Sci. 22: 927-931.

Saidaiah P, Satyanarayana E, Sudheer Kumar S. (2008). Association and path coefficient analysis in maize (Zea mays L.). Agric. Sci. Digest. 28(2): 79-83.

Saleem, M., Ahsan, M., Salam, M., Majeed, A. (2008). Comparative evaluation and correlation estimates for grain yield and quality attributes in maize. Pak.J. Bot. 40(6): 2361-2367.

Sali A, Imer R, Shukri F and Emilija S. (2012). Genetic diversity and correlation estimates for grain yield and quality traits in Kosovo local maize (Zea mays L.) populations. Acta Agric. Slovenica, 99( 2): 121-128.
SAS Institute Inc. (2007). SAS /STAT user's guide version 8, SAS Institute Inc. Cary, NC.

Sreckov Z, Bocanski J, Nastasic A, Dalovic I, Vukosavljev M. (2010). Correlation and path coefficient analysis of morphological traits of maize (Zea mays L.). Res J Agric Sci. 42(2): 292296.

Togay N, Togay Y, Yildirim B and Dogan Y (2008). Relationships between yield and some yield components in pea (Pisum sativum ssp arvense L.) genotypes by using correlation and path analysis. African Journal of Biotechnology Vol. 7 (23), pp. 42854287.

Troyer AF and Larkins JR (1985). Selection of early flowering in corn: 10 late synthetics. Crop Sci. 25: 695-697.

Westermann DT and Crothers SE (1977). Plant population effects on the seed yield components of beans. Crop Sci. 17: 493-496.

You LJ, Dong JP, GU YZ, Ma LL and Zhao S (1998). Target characteristics to develop for improved seed production in maize hybrids, J. Henan Agric. Sci. 10:3-4. 